\title{
ACADEMIC FREEDOM, HATE SPEECH, AND THE IDEA OF A UNIVERSITY
}

\author{
Rodney A. SMOLLA*
}

\section{INTRODUCTION}

The nation is in the midst of a fervent national debate over how universities should respond to "hate speech" on campuses.1 "Hate speech" is the generic term that has come to embrace the use of speech attacks based on race, ethnicity, religion, and sexual orientation or preference. ${ }^{2}$ This article analyzes this debate in two stages. The analysis begins by examining the existing state of first amendment jurisprudence regarding hate speech, exploring the doctrines that currently combine to protect such speech, the

Copyright (C) 1990 by Law and Contemporary Problems

- Arthur B. Hanson Professor of Law, and Director, Institute of Bill of Rights Law, College of William and Mary, Marshall-Wythe School of Law.

1. The debate has been prominent at virtually every college and university in the country in the last two years. See generally Steve France, Hate Goes to College, ABA J 44 (July 1990); Connie Leslie, Lessons from Bigotry 101: Racism on Campus, Newsweek 48-49 (September 25, 1989); Anti-Defamation League of B'nai B'rith Civil Rights Division, Campus Anti-Bias Codes: A New Form of Censorship? (1989) (policy background report); Crowd at Homecoming Boos Black Queen, Chron Higher Educ A2 (November 8, 1989); Cheryl M. Fields, Colleges Advised to Develop Strong Procedures to Deal With Incidents of Racial Harassment, Chron Higher Educ All (July 20, 1988); Robin Wilson, Colleges' Anti-Harassment Policies Bring Controversy Over Free-Speech Issues, Chron Higher Educ Al (October 4, 1989). It has received abundant attention in editorial pages. See, for example, Nat Hentoff, Campus Follies: From Free Speech ...., Washington Post A23 (November 4, 1989); George F. Will, Liberal Censorship, Washington Post C7 (November 5, 1989); Debra Everson, On Outlawing Hate Speech, Guild Notes 9 (November/December 1989); Charles R. Lawrence, III, The Debates Over Placing Limits on Racist Speech Must Not Ignore the Damage It Does to Its Victims, Chron Higher Educ Bl (October 25, 1989); James T. Laney, Why Tolerate Campus Bigots?, New York Times A35 (April 6, 1990); Paul R. Verkuil, Free to Speak, but Willing to Listen and Learn, New York Times A28 (April 25, 1990).

2. The issues latent in this definition, such as whether racial epithets should qualify as "speech" for constitutional purposes, are discussed in the text accompanying notes 37-57. The debate over hate speech has spawned a rich body of scholarly literature. See, for example, Kammy Au, Freedom from Fear, 15 Lincoln L Rev 45 (1984); Richard Delgado, Words That Wound: A Tort Action for Racial Insults, Epithets, and Name-Calling, 17 Harv CR-CL L Rev 133 (1982); Kent Greenawalt, Insults and Epithets: Are They Protected Speech?, 42 Rutgers L Rev 287 (1990); David Kretzmer, Freedom of Speech and Racism, 8 Cardozo L Rev 445 (1987); Kenneth Lasson, Group Libel Versus Free Speech: When Big Brother Should Butt In, 23 Duquesne L Rev 77 (1984); Charles R. Lawrence, III, If He Hollers Let Him Go: Regulating Racist Speech on Campus, 1990 Duke L J 431; Jean C. Love, Discriminatory Speech and the Tort of Intentional Infiction of Emotional Distress, 47 Wash \& Lee L Rev 123 (1990); Toni M. Massaro, Equality and Freedom of Expression: The Hate Speech Dilemma, 32 Wm \& Mary L Rev 211 (1991); Mari J. Matsuda, Public Response to Racist Speech: Considering the Victim's Story, 87 Mich L Rev 2320 (1989); Robert C. Post, Racist Speech, Democracy, and the First Amendment, 32 Wm \& Mary L Rev 267 (1991); Dean M. Richardson, Racism: A Tort of Outrage, 61 Ore L Rev 267 (1982); Rodney A. Smolla, Rethinking First Amendment Assumptions about Racist and Sexist Speech, 47 Wash \& Lee L Rev 171 (1990); Nadine Strossen, Regulating Racist Speech on Camprus: A Modest Proposal?, 1990 Duke LJ 484; R. George Wright, Racist Speech and the First Amendment, 9 Miss Col L Rev 1 (1988); Note, A Communitarian Defense of Group Libel Laws, 101 Harv L Rev 682 (1988). 
theoretical principles underlying those doctrines, and the narrow range of recognized exceptions to constitutional protection for speech that might, in some circumstances, permit hate speech to be punished.

The second stage of the analysis examines the relationship of these first amendment doctrines to notions of academic freedom at both state and private universities. Do the free speech rules prevailing in the general marketplace apply with equal force on university campuses? Or are there first amendment principles that either require or permit a different response to hate speech on campus than current first amendment doctrines allow in other contexts? ${ }^{3}$

II

Hate Speech and the First Amendment

\section{A. Contrasting "Affirmative" and "Negative" First Amendment Jurisprudence}

1. The "Affirmative" Side of Free Speech. The "affirmative" side of first amendment jurisprudence approaches free speech issues by emphasizing a group of interrelated doctrines that have combined, in modern times, to create a constitutional jurisprudence highly protective of freedom of speech. ${ }^{4}$ The affirmative side begins with the mindset that speech is presumptively protected against any restraint or punishment, and regards any encroachment with intense skepticism.

3. One of the principal issues in contemporary academic life is the question of the extent to which concepts of academic freedom have constitutional status. See, for example, University of Pennsylvania v EEOC, 110 S Ct 577, 586-87 \& n6 (1990); J. Peter Byrne, Academic Freedom: A "Special Concern of the First Amendment," 99 Yale L J 251 (1989); Walter P. Metzger, Profession and Constitution: Two Definitions of Academic Freedom in America, 66 Tex L Rev 1265 (1988); David M. Rabban, $A$ Functional Analysis of "Individual" and "Institutional" Academic Freedom Under the First Amendment, $53 \mathrm{~L} \&$ Contemp Probs 227 (Summer 1990); William W. Van Alstyne, The Specific Theory of Academic Freedom and the General Issue of Civil Liberty, in Edmund L. Pincoffs, ed, The Concept of Academic Freedom 59 (Univ of Texas Press, 1972); Mark G. Yudof, Three Faces of Academic Freedom, 32 Loyola L Rev 831 (1987). The issues in this debate are complicated, and their resolution will be influenced by, among other factors, whether the university in question is public or private. See University of Pennsylvania, $110 \mathrm{~S} \mathrm{Ct}$ at 587 n6 (suggesting that attempts by government to control the content of speech on private universities involve a different constitutional balance than regulation on public campuses, where government has interests both as a speaker and as the regulator). This article does not attempt to join issue on this generic question, but rather is limited to the specific legal and policy conflicts posed by hate speech. On a state university campus, regulation of hate speech is constrained directly by the first amendment. Since government is also in some contexts a "speaker" at a state university campus (as when a faculty member is speaking for the university), striking the appropriate first amendment balance is often complex. See notes 112.19 and accompanying text. A private university, of course, is not legally bound by the first amendment. When discussing the rules governing hate speech that a private university sets for itself, therefore, no issues of constitutional law are formally implicated. While not of first amendment dimension, the policy conflicts posed by hate speech regulations at private universities are, however, no different than those at public institutions. This article thus proceeds on the premise that the resolution of those conflicts pressed here are of equal validity for both public and private universities. See note 87 and accompanying text.

4. For an insightful and accessible illustration of the principle contending schools of first amendment interpretation during the past several decades, see William W. Van Alstyne, Interpretations of the First Amendment 21-40 (Duke Univ Press, 1984). 
The affirmative first amendment thinker is constantly looking for ways to stretch existing doctrines to embrace wider and wider protection for speech. Affirmative thinkers are unlikely to rest the justification for freedom of speech on any one theory, but instead point to a cluster of rationales for treating freedom of speech as a specially preferred social value. ${ }^{5}$ Most importantly, the affirmative side of first amendment jurisprudence emphasizes both the social value of free speech to the collective good and the private value of free speech to the individual. ${ }^{6}$

As a collective value, freedom of speech serves the general social interest in the pursuit of truth through the "marketplace of ideas." 7 Free speech also serves as a check on tyranny, ${ }^{8}$ and is the lifeblood of democratic selfgovernance. ${ }^{9}$ These collective theories justify free speech as a means to an end. But free speech is also an end in itself, an end intimately intertwined with human autonomy and dignity. ${ }^{10}$ Free speech is thus especially valuable for reasons that have nothing to do with the collective search for truth or the processes of self-government, or for any other conceptualization of the common good." It is a right to speak one's mind defiantly, robustly, and irreverently, just because it is one's mind. ${ }^{12}$

2. The "Negative" Side of Free Speech. The "negative" side approaches the first amendment as a problem to be got around whenever it interferes with

5. See generally Rodney A. Smolla, Law of Defamation \$ 1.07 (Clark Boardman, 1986); Edward J. Bloustein, The Origin, Validity, and Interrelationships of the Political Values Served by Freedom of Expression, 33 Rutgers L Rev 372, 395 (1981).

6. See Thomas Irwin Emerson, The System of Freedom of Expression 6-9 (Random House, 1970).

7. In the words of Oliver Wendell Holmes, Jr., "The best test of truth is the power of the thought to get itself accepted in the competition of the market." Abrams $v$ United States, 250 US 616 , 630 (1919) (Holmes dissenting). The "marketplace of ideas" is perhaps the most powerful metaphor in the free speech tradition. See generally Stanley Ingber, The Marketplace of Ideas: A Legitimizing Myth, 1984 Duke L J 1. In 1644, John Milton wrote in his Areopagitica: "And though all the winds of doctrine were let loose to play upon the earth, so Truth be in the field, we do injuriously by licensing and prohibiting to misdoubt her strength. Let her and falsehood grapple; who ever knew Truth put to the worse, in a free and open encounter?"

8. See Vincent Blasi, The Checking Value in First Amendment Theory, 1977 Am Bar Found Res J 521.

9. Free speech is an indispensable tool of self-governance in a democratic society. The Supreme Court has stated that "[w]hatever differences may exist about interpretations of the First Amendment, there is practically universal agreement that a major purpose of that Amendment was to protect the free discussion of governmental affairs." Landmark Communications, Inc. v Virginia, 435 US 829, 838 (1978), quoting Mills $v$ Alabama, 384 US 214, 218 (1966). Justice Louis Brandeis wrote that those who fought for America's independence believed that "freedom to think as you will and to speak as you think are means indispensable to the discovery and spread of political truth." Whitney $v$ California, 274 US 357, 375 (1927) (Brandeis concurring). See generally Alexander Meiklejohn, The First Amendment is an Absolute, $1961 \mathrm{~S} \mathrm{Ct}$ Rev 245.

10. See Martin H. Redish, The Value of Free Speech, 130 U Pa L Rev 591, 601-04 (1982); David A. J. Richards, Free Speech and Obscenity Law: Toward a Moral Theory of the First Amendment, $123 \mathrm{U}$ Pa L Rev 45, 62 (1974).

11. For a recent exposition on the value of freedom of speech as an aspect of individual liberty, see C. Edwin Baker, Human Liberty and Freedom of Speech (Oxford Univ Press, 1989).

12. Rodney A. Smolla, Suing the Press: Libel, the Media, and Power 257 (Oxford Univ Press, 1986). Even when the speaker has no realistic hope that the audience will be persuaded to his or her viewpoint, even when no plausible case can be made that the search for truth will be advanced, freedom to speak without restraint provides the speaker with an inner satisfaction and realization of self-identity essential to individual fulfillment. 
constructive social policy goals. The negative side begins with the proposition that the first amendment is not an absolute and that many recognized doctrines exist that permit speech to be regulated or punished. ${ }^{13}$ When presented with a problem such as hate speech, the negative first amendment thinker says: "Here are social policy values of enormous magnitude-equality, tolerance, and respect for human dignity-values that are, no less than free speech, of constitutional dimension. Let us employ every conceivable exception to protection for free expression that is currently recognized, so that hate speech can be deterred and these laudable values vindicated."

The negative first amendment thinker accepts freedom of speech as an important constitutional value, but, when matters such as hate speech are at issue, tends to look for ways to stretch the loopholes. The negative thinker will tend to punch holes in the many classic rationales that have been advanced to support expansive protection of freedom of speech. The poetic power of the marketplace image, it is pointed out, is tempered by experience. ${ }^{14}$ Grounding freedom of speech in individual fulfillment, it is argued, is inappropriate, for then freedom of speech becomes indistinguishable from any other human desire, losing any claim to unique

13. See generally Harry H. Wellington, On Freedom of Expression, 88 Yale L J 1105 (1979).

14. When subjected to severe cross-examination, no single justification for freedom of speech is likely to come through perfectly unscathed, and the marketplace rationale is no exception.

The marketplace of ideas is a marketplace, and like all markets, it may experience positive and negative cycles. The marketplace image is grounded in laissez-faire economic theory. Even if we are to accept the apparent lesson of perestroika that, on the whole, free economic markets perform more efficiently than controlled economies, almost all governments utilize some controls on markets to correct for excesses and imperfections that can lead to violent economic swings. The theoretical purity of the models in economic textbooks is not matched by the actual performance of markets in the mundane commercial world. Economists concede the necessity of using governmental regulation to trim the freedom of markets at the edges, correcting their deficiencies in the real world of commerce. See generally C. Edwin Baker, Scope of the First Amendment Freedom of Speech, 25 UCLA L. Rev 964, 974-78 (1978); Ingber, 1984 Duke L J at 4-5 (cited in note 7).

The marketplace of ideas rationale is also ostensibly contradicted by our everyday experience. There are as many shoddy ideas circulating as there are shoddy products. If the marketplace produces truth, the persistence of falsity seems difficult to explain. Is there any reason to be confident that good thoughts drive out bad ones? Nazis and the Ku Klux Klan continue to parade in America, and racial separatism continues as the formal law of South Africa. The belief in racial and ethnic superiority is still in wide currency throughout the world, from ethnic strife in the Soviet republics to the tense racial politics of New York City and Washington, D.C. Institutions and individuals across the globe continue to espouse and practice the dominance and exploitation of women. See generally Wellington, 88 Yale $\mathrm{L} J$ at $1130-32$ (cited in note 13 ).

The hope that the marketplace will lead to truth is further eroded by the infiltration of emotional distortions into the realm of "ideas." Irrational appeals to hate and prejudice have, throughout the experience of man, often overwhelmed thoughtful tolerance and understanding, leading to violence and destruction. Even if we were to accept the marketplace of ideas model as valid, therefore, it would remain to be decided what would count as an "idea." Would it necessarily encompass appeals to hate that shortcut the mind and speak from heart to heart, or could it be limited to speech asserting intellectual propositions? See notes $27-28$ and accompanying text.

Finally, there is a curiously ironic shortcoming to the marketplace image. We can never empirically test the proposition that truth will triumph over error, because that would itself require some objective measure of what ideas are true and what ideas are false-a measurement that the marketplace theory appears to forbid. Benjamin S. DuVal, Jr., Free Communication of Ideas and the Quest for Truth: Toward a Teleological Approach to First Amendment Adjudication, 41 Geo Wash L Rev 161, 190-91 (1972). 
shelter from interference by the state. ${ }^{15}$ Significantly, the negative free speech thinker is likely to single out one narrow rationale for elevating protection of free expression-the significance of freedom of speech to the process of self-governance-thus treating political speech as the only genre of expression meriting heightened protection. ${ }^{16}$

3. Free Speech Theory in the Supreme Court. In the last three decades, the affirmative side of free speech thinking has generally triumphed over the negative. The Supreme Court has tended to accept the affirmative argument that freedom of speech is a preferred value supported by multiple rationales, extending generous levels of constitutional protection to a vast range of expression. Despite the marketplace metaphor's frailties, the Court has enthusiastically embraced it. ${ }^{17}$ The Court has declined the invitation to limit first amendment protection to political speech. While recognizing in many cases that political speech lies at the core of the first amendment, ${ }^{18}$ it has nevertheless insisted that the "guarantees for speech and press are not the preserve of political expression or comment upon public affairs, essential as those are to healthy government." 19 The Court has declared that the free speech and free press guarantees "are not confined to any field of human interest,"20 and that "it is immaterial whether the beliefs sought to be advanced ... pertain to political, economic, religious or cultural matters ."21 Most significantly, the Court has acknowledged that the first amendment "serves not only the needs of the polity but also those of the human spirit—a spirit that demands self-expression." 22

15. The self-fulfillment rationale has an almost unseemly ring of hedonism. Speakers claim protection for the sheer pleasure of speaking. The objection might thus be made that to ground freedom of speech in the self-fulfillment theory is to indulge the individual in a right of selfgratification that legal systems have traditionally not been obliged to respect. An individual may derive pleasure and fulfillment from many activities other than speech, and so the pleasure principle seems insufficient by itself to justify atypical rules for speech. Individuals may also seek pleasure or fulfillment by taking cocaine or having sex with a prostitute, but those two activities have not, traditionally, been deemed outside the legitimate regulation of the state. Many nonspeech activities through which individuals seek pleasure have conventionally been deemed by society as either illicit or illegal or both, even when they involve no immediate victims, on the theory that they may tend to cause harm. If protection of speech is linked to the pursuit of pleasure, then the state should be permitted to regulate speech in the same manner as it regulates other pleasure-seeking activity. See Robert H. Bork, Neutral Principles and Some First Amendment Problems, 47 Ind L J 1, 26-28 (1971).

16. See generally Alexander Meiklejohn, Free Speech and its Relation to Self-Government 15-16, 24-27 (Harper, 1948); Robert H. Bork, The Tempting of America: The Political Seduction of the Law 333 (Free Press, 1990).

17. See, for example, Milkovich v Lorain Journal Co., 110 S Ct 2695, 2705 (1990); Hustler Magazine, Inc. $v$ Falwell, 485 US 46, 50-51 (1988); New York Times Co. $v$ Sullivan, 376 US 254, 270 (1964).

18. See note 9 .

19. Time, Inc. v Hill, 385 US 374, 388 (1974).

20. United Mine Workers v Illinois Bar Ass' $n, 389$ US 217,223 (1967), quoting Thomas $v$ Collins, 323 US $516,531(1945)$.

21. NAACP v Alabama, 357 US 449, 460 (1958). See also Abood v Detroit Board of Educ., 431 US 209,223 (1977).

22. Procunier $v$ Martinez, 416 US 396, 427 (1974). The Court has thus found unpersuasive the arguments of theorists such as Robert Bork that the self-fulfillment rationale for free speech fails to distinguish speech from any other human desire. See Bork, 47 Ind L J 1 (cited in note 15). Two strong arguments may be asserted against Judge Bork's position. The first is a broad libertarian 


\section{B. Hate Speech and the Affirmative Side of the First Amendment}

There are a number of modern affirmative first amendment doctrines that interlock to create a large measure of protection for hate speech.

1. Neutrality. The neutrality principle embraces a cluster of precepts that form the core of modern first amendment jurisprudence. Mere opposition to an idea is never enough, standing alone, to justify the abridgment of speech. ${ }^{23}$ Government may not pick and choose among ideas, but must always be "viewpoint neutral."24 All ideas are created equal in the eyes of the first amendment-even those ideas that are universally condemned and run

attack on the underlying premise that government may control most activities of human life if it can simply point to reasonable grounds for doing so. A libertarian would argue that the presumption should be exactly the opposite: government normally may not intervene in an individual's affairs, and is justified in doing so only to the extent necessary to prevent the individual from harming others. This means that many pleasure-seeking activities are beyond the legitimate jurisdiction of the state altogether, because they harm only the individual who engages in them. The "harm requirement" may not be satisfied merely by the outrage or moral opprobrium that the majority attaches to the activity. Crimes must have victims-victims other than the perpetrator. In a society organized under strict libertarian principles, free speech receives protection far higher than unweighted balancing for the same reasons that many other forms of activity are protected: because government is often unable to point to palpable harm caused by the activity. One need not adopt the complete libertarian argument, however, to defeat the position that self-fulfilment is mere selfgratification, and thus an insufficient basis for special protection for speech. A second, more modest argument treats the self-fulfillment aspect of speech as qualitatively different from other forms of gratification, and therefore critically important even if one is not a card-carrying libertarian. A persuasive case can be made that speech is a form of self-gratification different in kind from most other forms of self-fulfilment, and therefore deserving of special solicitude. We may start by quibbling on terms. To articulate the theory in terms of "pleasure" and "gratification" is to trivialize it. The term "self-fulfillment" connotes much more than hedonistic pleasure and gratification. The words "pleasure" and "gratification" emphasize those aspects of human life that resemble the lives of animals; the term "self-fulfillment" emphasizes those aspects of humanity that distinguish human beings from other species. The fulfilment that comes from speech is bonded to the human capacity to think, imagine, and create. Conscience and consciousness are the sacred precincts of mind and soul. The linkage of speech to thought, to each person's central capacity to reason and wonder, is what places it above other forms of fulfilment, and beyond the routine jurisdiction of the state. See generally Baker, Human Liberty and Freedom of Speech (cited in note 11); Redish, $130 \mathrm{U}$ Pa L Rev at 601 04 (cited in note 10); Richards, $123 \mathrm{U} \mathrm{Pa} \mathrm{L} \mathrm{Rev} \mathrm{at} 62$ (cited in note 10).

23. See, for example, Ward v Rock Against Racism, 109 S Ct 2746, 2754 (1989) ("The principal inquiry in determining content neutrality ... is whether the government has adopted a regulation of speech because of disagreement with the message it conveys.").

24. See, for example, Cormelius v NAACP Legal Defense É Educ. Fund, 473 US 788, 806 (1985); Perry Educ. Ass'n v Perry Local Educators' Ass'n, 460 US 37, 46, 49 n9 (1983). See generally Robert C. Post, Between Governance and Management: The History and Theory of the Public Forum, 34 UCLA L Rev 1713, 1824 (1987). 
counter to constitutional principle. ${ }^{25}$

While the first amendment is not an absolute, the neutrality principle is. ${ }^{26}$

2. The Emotion Principle. Constitutional protection for speech is not limited to its cognitive content alone, but extends also to the emotional components of speech. ${ }^{27}$ Speech does not forfeit the protection that it would otherwise enjoy merely because it is laced with passion or vulgarity. ${ }^{28}$

25. This notion had its most famous articulation in a defamation case, Gertz $v$ Robert Welch, Inc., 418 US 323, 339-40 (1974): "Under the First Amendment there is no such thing as a false idea. However pernicious an opinion may seem, we depend for its correction not on the conscience of judges and juries but on the competition of other ideas." In Milkovich, $110 \mathrm{~S} \mathrm{Ct}$ at 2705, another defamation case, the Supreme Court recently held that "the fair meaning of the Gertz passage is to equate the word 'opinion' in the second sentence with the word 'idea' in the first sentence." In Milkovich, the Court refused to create a special constitutional doctrine creating "a wholesale defamation exemption for anything that might be labeled 'opinion.'" Id. Instead, the Court read the Gertz passage as a restatement of the "marketplace of ideas" concept. Id. See note 7 and accompanying text.

26. "If there is a bedrock principle underlying the First Amendment, it is that the Government may not prohibit the expression of an idea simply because society finds the idea offensive or disagreeable." Texas v Johnson, $109 \mathrm{~S} \mathrm{Cl}$ 2533, 2544 (1989), citing Hustler, 485 US at 55-56; City Council of Los Angeles $v$ Taxpayers for Vincent, 466 US 789, 804 (1984); Bolger $v$ Youngs Drug Products Corp., 463 US 60, 65, 72 (1983); Carey v Brown, 447 US 455, 462-63 (1980); FCC v Pacifica Foundation, 438 US 726, 745-46 (1978); Young v American Mini Theatres, Inc., 427 US 50, 63-65, 67-68 (1976); Buckley $v$ Valeo, 424 US 1, $16-17$ (1976); Grayned v Rockford, 408 US 104, 115 (1972); Police Dept. of Chicago $v$ Mosley, 408 US 92, 95 (1972); Bachellar v Maryland, 397 US 564, 567 (1970); United States v O'Brien, 391 US 367, 382 (1968); Brown v Louisiana, 383 US 131, 142-43 (1966); Stromberg v Califormia, 283 US 359, 368-69 (1931).

27. In Cohen v California, 403 US 15 (1971), for example, the Supreme Court held that it was unconstitutional for the State of California to convict the defendant for wearing a jacket plainly bearing the phrase "Fuck the Draft" in a Los Angeles courthouse corridor where women and children were present.

Several points in Cohen merit special emphasis. First, the Court unequivocally rejected the notion that a state may seek to prevent the use of vulgarity merely for the purpose of cleansing public discourse and sheltering citizens from offensive language:

How is one to distinguish this from any other offensive word? Surely the State has no right to cleanse public debate to the point where it is grammatically palatable to the most squeamish among us. Yet no readily ascertainable general principle exists for stopping short of that result were we to affirm the judgment below. For, while the particular fourletter word being litigated here is perhaps more distasteful than most others of its genre, it is nevertheless true that one man's vulgarity is another's lyric.

Id at 25

Second, the Court made it clear that the shock value of Cohen's language did not justify the California law. The Court rejected the assertion that the state could excise "one particular scurrilous epithet from the public discourse, either upon the theory ... that its use is inherently likely to cause violent reaction or upon a more general assertion that the States, acting as guardians of public morality, may properly remove this offensive word from the public vocabulary." Id at 22-23.

Finally, the Court held that it made no difference that some members of the general public would inadvertently be exposed to Cohen's vulgarity. Id at 22. The Cohen decision, it must be remembered, involved the quintessential example of lewd or profane language-indeed, the single most offensive word in the American vocabulary. Further, the case arose inside a courthouse, a setting in which the state traditionally has substantially more right to regulate speech than it has in the public streets.

28. In Hustler, 485 US 46, the Court was faced with a crude parody run by Hustler Magazine depicting Reverend Jerry Falwell as an incestuous drunk. The Court ruled without dissent that the parody was protected under the first amendment. Chief Justice Rehnquist conceded that the Hustler parody was at best a distant cousin of the conventional political cartoon, "and a rather poor relation at that." Id at 55. Rehnquist argued, however, that there was simply no way to draw a principled distinction between the Hustler parody and other satiric efforts. "If it were possible," he stated, "by laying down a principled standard to separate the one from the other, public discourse would 
3. The Symbolism Principle. First amendment protection is not limited to the use of language, but also includes expressive conduct, such as mass demonstrations or communication through the use of symbols. ${ }^{29}$

4. The Harm Principle. While the neutrality principle forbids penalizing speech merely because of opposition to its content, modern first amendment jurisprudence does permit speech to be penalized when it causes harm. The harm principle defines the types of injuries that will qualify as harms sufficient to justify regulation of speech. ${ }^{30}$ The harm principle is a natural corollary to

probably suffer little or no harm." Id. But the Supreme Court was doubtful, Rehnquist explained, that any reasonably concrete standard could ever be articulated. Amorphous pejoratives such as "outrageous" or "indecent" were too subjective to withstand first amendment requirements. To permit a jury to impose liability for mere "outrageousness" would invite jurors to base liability on the basis of their tastes and prejudices. Id at 55. See generally, Rodney A. Smolla, Jerry Falwell v. Larry Flynt: The First Amendment on Trial (St. Martin's Press, 1988); Paul A. LeBel, Emotional Distress, the First Amendment, and "This Kind of Speech": A Heretical Perspective on Hustler Magazine v. Falwell, 60 U Colo L Rev 315 (1989); Robert C. Post, The Constitutional Concept of Public Discourse: Outrageous Opinion, Democratic Deliberation, and Hustler Magazine v. Falwell, 103 Harv L Rev 601 (1990); Rodney A. Smolla, Emotional Distress and the First Amendment: An Analysis of Hustler v. Falwell, 20 Ariz L J 423 (1988)

29. As early as 1931, the Court had recognized that the constitutional protections for speech extended to more than the use of language, encompassing communication through the use of nonlanguage symbols. In Stromberg v Califormia, 283 US 359 (1931), the Court struck down a state statute that barred displaying of a red flag " 'as a sign, symbol or emblem of opposition to organized government ....'”Id at 361, quoting Cal Penal Code $\$$ 403-a (repealed 1933). The Court ruled that the statute was so vague that it threatened "the opportunity for free political discussion." Id at 369.

The Court's most dramatic confrontations with attempts to punish symbolic speech came in the recent round of flag-desecration cases. In Texas v Johnson, $109 \mathrm{~S}$ Ct 2533 (1989), the Court overturned the conviction of Gregory Lee Johnson, who had burned an American flag as part of a protest during the Republican National Convention in Dallas. Justice William Brennan's opinion for the majority was a ringing celebration of freedom of speech. The Texas statute singled out "only those severe acts of physical abuse of the flag carried out in a way likely to be offensive." Id at 2543 , quoting Brief for Petitioner at 44. Because the conviction rested on "the likely communicative impact of [the] expressive conduct," Brennan reasoned that the state was regulating "emotive impact." Id. This was inconsistent with the principle that speech may never be proscribed merely because society finds its intellectual or emotional message disagreeable. Id at 2544 .

United States v Eichman, 110 S Ct 2404 (1990), was the sequel to Johnson in which the Court struck down the federal Flag Protection Act of 1989, 18 USCA $\$ 700$ (West Supp 1990). Justice Brennan's opinion in Eichman, rendered only a little more than a month after the cases had been orally argued before the Court, was flat, matter-of-fact, and brief-barely eight pages long. "Although Congress cast the Flag Protection Act in somewhat broader terms than the Texas statute at issue in Johnson," Justice Brennan wrote, "the Act still suffers from the same fundamental flaw: it suppresses expression out of concern for its likely communicative impact." Id at 2409. Brennan's opinion repeated, in relatively summary fashion, the analysis in Johnson. The government may foster patriotism and national unity by persuasion and example, he maintained, but not by criminalizing symbolic speech. Id at 2409, quoting Johnson, $109 \mathrm{~S}$ Ct at 2547, quoting West Virginia Board of Education v Barnette, 319 U.S. 624, 640 (1943). Brennan's opinion made only an oblique reference to the political controversy swirling around the flag-burning issue, stating, "We are aware that desecration of the flag is deeply offensive to many." Id at 2410 . But the same might be said, he pointed out, of virulent ethnic and religious epithets, vulgar repudiations of the draft, and scurrilous caricatures, all of which were protected under the first amendment. Id at 2410, citing Terminiellov Chicago, 337 US 1 (1949) (religious and ethnic attacks); Cohen, 403 US 15 (vulgar draft protest); Hustler, 485 US 46 (vicious caricature).

30. See generally John Stuart Mill, On Liberty (1859), reprinted in On Liberty, Representative Government, The Subjection of Women: Three Essays by John Stuart Mill 5 (Oxford Univ Press, 1952); Smolla, 47 Wash \& Lee L Rev at 175-76 (cited in note 2); T. M. Scanlon, Jr., Freedom of Expression and Categories of Expression, 40 U Pitt L Rev 519 (1979). 
the neutrality and emotion principles, serving to preserve the integrity of those two doctrines.

The possible harms caused by speech may be divided into three categories: physical harms, relational harms, and reactive harms.

(a) Physical Harms. Speech may cause physical harms to persons or property in a variety of ways. Speech may be used to negotiate a contract soliciting a murder, or to commission an arsonist to burn down a building. Speech may be used to whip an angry crowd of protesters into an emotional frenzy, inciting them to storm barricades and throw rocks at police. The physical violence caused by these examples carries out the wishes of the speaker. Speech may also cause violence counter to the speaker's interests, as when those who hear the message are so outraged that they are moved to physical assault against the speaker.

(b) Relational Harms. Speech may interfere with relationships of various kinds, including social relationships, commercial transactions, proprietary interests in information, and interests in the confidentiality of communications.

(c) Reactive Harms. Speech can cause reactive harms-injuries caused by emotional or intellectual responses to the content of the speech. These reactive harms may be felt by individuals, or they may be harms conceptualized in some collective sense, such as injuries to community values of morality or civility.

This taxonomy of harms is represented in the chart on the following page: 


\section{Chart 1 \\ The Harms Chart}

Category I: Physical Harms

INJURIES to PERSONS

Examples:

-Solicitation of murder

-Incitement to riot on behalf of the speaker's cause

-Reactive violence against the speaker in response to the message

Injuries to Property

Examples:

-Solicitation of arson

-Incitement to destroy property

-Reactive violence against the property of the speaker in response to the message

\section{Category II: Relational Harms}

INJURies to SOCIAL ReLATIONSHips

Examples:

- Libel and slander

-Alienation of affections

INJURIES to Transactions or BUSINESS RELATIONSHIPS

Examples:

-Fraud and misrepresentation

- False advertising

-Interference with contractual relations

-Interference with prospective economic advantage

-Insider trading

INJURIES TO INFORMATION OWNERSHIP INTERESTS

Examples:

-Copyright, trademark, or patent infringement

-Appropriation of name or likeness for commercial purposes

INJURIES TO INTERESTS IN CONFIDENTIALITY

Examples:

-Disclosure of national security secrets

-Unauthorized revelation of private personal information

\section{Category III: Reactive Harms}

InJURIES TO INDIVIDUAL EMOTIONAL TRANQUILITY

Examples:

-Infliction of emotional distress

- Invasion of privacy caused by placing the individual in a false light in the public eye

--Invasion of privacy involving intrusion upon seclusion

- Invasion of privacy involving publication of embarrassing facts

-Distress caused by intellectual disagreement with the content of the speech

Injuries to Communal Sensibilities

Examples:

- Insults to human dignity, such as racist or sexist speech

-Vulgarity

-Obscenity

- Interference with political or social cohesiveness or harmony arising from collective disagreement with the content of speech

Though the harms resulting from speech are often limited to only one category, the three categories above are not mutually exclusive. The harms may be a blend of more than one of the categories, and any given act of 
speech may simultaneously result in all three categories of harms. For example, a speaker might utter a slanderous remark to someone in a face-toface confrontation that leads to fisticuffs between the speaker and his victim. The remark might in turn be heard by others with whom the victim has social or business relationships, thus interfering with those relationships. Finally, the remark might cause the victim and others in the community to experience powerful feelings of disgust and revulsion. ${ }^{31}$

The three categories represent a hierarchy of governmental justifications for regulating speech. Government has the strongest case for regulating speech posing risks of physical harms. Government's justifications for regulating speech posing risks of relational harms are quite strong, though not as forceful as for physical harms.

The harms posed in Category III may not be used as justifications for regulation of speech. This rule simply restates the neutrality and emotion principles: neither intellectual nor emotional revulsion to speech is ever enough, standing alone, to justify its abridgment-government must instead demonstrate an invasion of one of the more palpable physical or relational harms listed in Categories I or II.

5. The Causation Principle. The integrity of the neutrality, emotion, and harm principles is dependent upon the adoption of a rigorous causation rule that requires a close causal nexus between speech and harm before penalizing speech. The modern "clear and present danger" test is the most famous articulation of the currently prevailing causation rule. In its current form, the test provides that advocacy of force or criminal activity may not be enough unless "such advocacy is directed to inciting or producing imminent lawless action and is likely to incite or produce such action." 32 Without a strict causation test, government will tend to slip surreptitiously into penalizing opinions, and into permitting regulation of speech purely because of the

31. Alternatively, any given act of communication might be relatively pure, implicating only one type of harm. For example, a speaker might copy verbatim from someone else's copyrighted work and sell the copies for profit, without permission from the copyright owner. This could interfere with a relational ownership interest, but not pose any risk of physical harm or cause any negative emotional or intellectual reaction in persons exposed to the speech. (The owner of the copyright might, of course, be emotionally upset that someone has pirated his or her work-but that emotional disturbance is not in reaction to the actual message but rather to the theft of his or her intellectual property.)

32. Brandenburg $v$ Ohio, 395 US 444, 447 (1969). Brandenburg involved a Ku Klux Klan rally conducted on a farm in Hamilton County, Ohio, outside Cincinnati. A local Cincinnati television station reporter had been invited to witness the rally, and he and a cameraman filmed the event, portions of which were later broadcast on the Cincinnati station and a national network. Id at 445 . The film footage is filled with vile, incendiary racist bile. Klan members pronounced that "the nigger should be returned to Africa, the Jew returned to Israel," and "if our President, our Congress, our Supreme Court, continues to suppress the white, Caucasian race, it's possible that there might have to be some revengeance [sic] taken." Id at 446-47.

The state of Ohio prosecuted Brandenburg, the leader of the Klan group, under an Ohio criminal syndicalism law, which made it illegal to advocate "the duty, necessity, or propriety of crime, sabotage, violence, or unlawful methods of terrorism as a means of accomplishing industrial or political reform," or to assemble "with any society, group, or assemblage of persons formed to teach or advocate the doctrines of criminal syndicalism." Id at 444-45, quoting Ohio Rev Code Ann 
reactive disturbances it causes. Virtually any opinion might, at some indeterminate future time, "cause" physical harm. ${ }^{33}$ Similarly, the emotional and intellectual reactions of others to speech might ripen into violent physical reactions at some indeterminate future time. A society will never have robust freedom of speech if any threat of future physical harm is enough to justify speech regulation.

\section{The Precision Principle. Precision is a pervasive theme of modern first} amendment analysis. Even when regulation of speech is otherwise justified (as when a compelling governmental interest is at stake), the regulation will be struck down if it fails to meet both substantive and definitional precision requirements. A substantive principle requires that regulatory mechanisms implicating speech be precisely designed to effectuate the governmental interest at stake. ${ }^{34} \mathrm{~A}$ parallel rule of definitional precision requires that the

$\S 2923.13$ (repealed 1974). Brandenburg was convicted, fined $\$ 1,000$, and sentenced to one to ten years' imprisonment. Id at 445.

The Court held the Ohio law unconstitutional. Id at 448. No one was present at the Klan rally except the Klan members themselves, the television reporter, and his cameraman. Id at 445-46. Nothing in the record indicated that the orgy of race hate posed any immediate physical threat to anyone, and the statute, either as written or applied in this case, does nothing to distinguish "mere advocacy" from "incitement to imminent lawless action." Id at 448-49. In these circumstances, the Court said, the Klan was guilty only of the "abstract teaching" of the "moral propriety" of racist violence. Id at 448, quoting Noto v United States, 367 US 290, $297-98$ (1961). "[T]he constitutional guarantees of free speech and free press," according to the Court, "do not permit a State to forbid or proscribe advocacy of the use of force or of law violation except where such advocacy is directed to inciting or producing imminent lawless action and is likely to incite or produce such action." Id at 447.

33. In Hess $v$ Indiana, 414 US 105 (1973), the defendant Gregory Hess was convicted of violating Indiana's disorderly conduct statute in an anti-Vietnam $W$ ar demonstration on the campus of Indiana University. Between $10 \mathrm{~b}$ and 150 demonstrators had moved onto a public street, blocking traffic. After refusing to obey the sheriff's command to clear the street, the demonstrators were moved to the curbs by the sheriff and his deputies. Id at 106. As the sheriff passed by Hess, Hess said, "We'll take the fucking street later." The sheriff immediately arrested Hess for disorderly conduct, and he was convicted. Id at 107 .

The Supreme Court reversed the conviction, holding that Hess could not be convicted merely for having used the word "fuck," since that word standing alone did not satisfy the legal definition of obscenity. Id. Nor could Hess's statement be seen as a direct verbal challenge to fight the sheriff or his deputies-witnesses testified that he was facing the crowd, not the street, when he made the statement and that his words did not appear to be addressed to any particular person or group. Id at 107-08. Turning to the Brandenburg standard, the Court held that Hess was not guilty of any incitement to imminent lawless action. Id at 108-09. The words "We'll take the fucking street later," the Court maintained, could be taken as a counsel for "present moderation" or as advocacy of illegal action "at some indefinite future time," neither of which were enough to constitute a present threat of imminent disorder. Id at 108.

34. This substantive precision principle is a component of both the "strict scrutiny" level of judicial review applicable to content-based regulation of speech and the reduced level of scrutiny applicable to non-content-based regulation. See, for example, Sable Communications of California, Inc. v FCC, 109 S Ct 2829, 2836 (1989) (government may only "regulate the content of constitutionally protected speech in order to promote a compelling interest if it chooses the least restrictive means to further the articulated interest"); $O^{\prime}$ Brien, 391 US at 377 (When government regulation is "unrelated to the suppression of free expression," the "incidental restriction on alleged First Amendment freedoms" must be "no greater than is essential to the furtherance of that interest."). See also Board of Trustees of State University of New York v Fox, 109 S Ct 3028, 3035 (1989)(requiring a "reasonable" fit between means and ends in commercial speech cases). These substantive first amendment standards are discussed in greater detail in notes 54-58 and accompanying text. 
terms used to identify proscribed speech be defined with a meticulous exactitude well beyond that of other routine legislation, so that speakers know in advance what speech is and is not permitted, thereby avoiding the selfcensorship caused by uncertainty. ${ }^{35}$

\section{Hate Speech and the Negative Side of the First Amendment}

Modern first amendment jurisprudence does permit expression to be penalized in a number of circumstances arguably applicable to hate speech.

1. The Two-Class Theory. Back in an older and simpler time in the history of free expression, the Supreme Court appeared to espouse a theory that treated certain types of expression as taboo forms of speech, beneath the dignity of the first amendment. ${ }^{36}$ The most celebrated statement of this view appeared in Chaplinsky v. New Hampshire: ${ }^{37}$

There are certain well-defined and narrowly limited classes of speech, the prevention and punishment of which have never been thought to raise any Constitutional problem. These include the lewd and obscene, the profane, the libelous, and the insulting or "fighting" words-those which by their very utterance inflict injury or tend to incite an immediate breach of the peace. ${ }^{38}$

Hate speech is clearly within the Chaplinsky litany. In common sense understanding a vulgar racial slur may variously be described as "lewd," "obscene," "profane," "libelous," or "insulting," and thus the very type of expression "the prevention and punishment of which have never been thought to raise any Constitutional problem." And indeed, in 1952, when this two-class theory of the first amendment was still flourishing, the Court upheld a criminal conviction for spreading racist hate speech. In Beauharnais $v$. Illinows, ${ }^{39}$ the Court was faced with a criminal libel case involving an Illinois statute that criminalized any publication portraying "depravity, criminality, unchastity, or lack of virtue of a class of citizens, of any race, color, creed or religion" exposing them "to contempt, derision, or obloquy or which is productive of breach of the peace or riots." 40 The defendant Beauharnais was president of a racist Chicago organization, the White Circle League, which had distributed racist leaflets. ${ }^{41}$

35. The first amendment thus imposes meticulous tolerance levels on the "engineering" utilized in speech laws. This is reflected in rules such as the "overbreadth" and "vagueness" doctrines. See Broadrick v Oklahoma, 413 US 601 (1973); Gooding v Wilson, 405 US 518 (1972); Baggett v Bullitt, 377 US 360 (1964).

36. See generally Harry Kalven, $A$ Worthy Tradition: Freedom of Speech in America 77-106 (Harper \& Row, 1988).

37. 315 US 568 (1942).

38. Id at 571-72, citing Zechariah Chafee, Free Speech in the United States (Harvard Univ Press, 1941).

39. 343 US 250 (1952).

40. Id at 251, quoting Ill Rev Stat ch 38, § 471 (1949).

41. Id at 252. The leaflets called on the mayor and city council of Chicago "to halt the further encroachment, harassment and invasion of white people, their property, neighborhoods and persons, by the Negro," and exhorted "[o]ne million self respecting white people in Chicago to unite," proclaiming that "[i]f persuasion and the need to prevent the white race from becoming 
In his defense to the Illinois criminal prosecution, Beauharnais asked that the jury be instructed that he could not be found guilty unless the leaflets were "likely to produce a clear and present danger of a serious substantive evil that rises far above public inconvenience, annoyance or unrest." 42 The Illinois court refused to use this instruction, and Beauharnais was convicted. ${ }^{43}$ The United States Supreme Court affirmed, in an opinion by Justice Felix Frankfurter. ${ }^{44}$ If such a two-class theory of the first amendment still survived, hate speech could be punished with impunity. But the theory is no longer viable; modern first amendment principles have passed it by, ${ }^{45}$ and Beauharnais is no longer good law. The Court no longer accepts the view that speech may be proscribed merely because it is "lewd," "profane," or otherwise vulgar or offensive-the decisions in cases such as Cohen ${ }^{46}$ and Hustler ${ }^{47}$ are illustrative-and libelous speech is no longer beyond first amendment protection. ${ }^{48}$ Only one small piece of the two-class theory survives: the Court continues to treat "obscene" speech as not within the protection of the first amendment at all. 49

2. The Fighting Words Doctrine. While the methodology of Chaplinksy has been repudiated (for all but obscene speech), the so-called "fighting words" doctrine remains alive, as modified by the current rigorous clear and present danger test. Thus a verbal attack directed at a particular individual in a faceto-face confrontation that presents a clear and present danger of a violent

mongrelized by the negro will not unite us, then the aggressions . . . rapes, robberies, knives, guns and marijuana of the negro, surely will." Id.

42. Id at 253.

43. Illinois $v$ Beauharnais, 408 Ill 512, 97 NE2d 343 (1951).

44. Justice Frankfurter's opinion contained only a short-but interesting-discussion of freedom of speech. It had been argued against the Illinois law that prohibiting libel of a creed or a racial group is "but a step from prohibiting libel of a political party." 343 US at 263 . Frankfurter clearly thought, however, that a sharp first amendment distinction existed between restrictions on political speech and restrictions relating to "race, color, creed or religion." Id at $263 \mathrm{n} 18$. These terms, he insisted, had "attained too fixed a meaning to permit political groups to be brought within" their rubric, and for Frankfurter that rubric was apparently outside the protections of the first amendment. Id. "Of course," he noted, "discussion cannot be denied and the right, as well as the duty, of criticism must not be stifled." Id at 264. But for Frankfurter there was nothing "political" about this speech, nor did it rise to the level of "discussion." "If a statute sought to outlaw libels of political parties," he conceded, "quite different problems not now before us would be raised." Id at $263 \mathrm{n} 18$. Frankfurter was confident that " $[w]$ hile this Court sits, it retains and exercises authority to nullify action which encroaches on freedom of utterance under the guise of punishing libel." Id at 263-64 (citation omitted).

45. See Cohen, 403 US 15; Hustler, 485 US 46.

46. 403 US 15.

47. 485 US 46 .

48. In a line of cases emanating from Sullivan, 376 US 254, the Court has created significant first amendment protections for libelous speech. See Philadelphia Newspapers, Inc. v Hepps, 475 US 767 (1986); Gertz, 418 US 323.

49. In Roth v United States, 354 US 476, 485 (1957), the Court held that "obscenity is not within the area of constitutionally protected speech or press." The legal definition of obscenity has gone through several mutations since Roth, but the basic principle that obscene speech is not constitutionally protected remains. See Pope v Illinois, 481 US 497 (1987); Miller v California, 413 US $15(1973)$. 
physical reaction may be penalized. ${ }^{50}$ A statute aimed at hate speech that only penalizes such "fighting words" confrontations, and that is applied to require a governmental showing of imminent danger in every individual case, would be constitutional. ${ }^{51}$ Such a statute or regulation might also be symbolically valuable, for it at least makes some statement concerning human dignity and the repugnance of society for hate speech attacks. A mere fighting words statute, however, will reach only a small percentage of hate speech. ${ }^{52}$

\section{Content-Neutral Protection of Persons or Property. The clear and present} danger test permits speech to be penalized when it is on the brink of erupting into violence against persons or property. ${ }^{53}$ Once physical injury to persons or property has taken place, criminal and tort rules of general application may be brought to bear upon the wrongdoer, and it is no defense that the persons were injured or the property destroyed in the cause of free expression. There is no first amendment right to commit physical assault or damage another's property. Under the principles established in United States $v$. O'Brien, ${ }^{54}$ when the government promulgates a rule for reasons unrelated to the content of

50. In Cohen, 403 US at 20, the Court "restated" the fighting words doctrine of Chaplinsky, superimposing upon it the requirements of a rigorous clear and present danger test. The Court in Cohen thus emphasized that in that case no one was present who would have regarded Paul Cohen's speech as a "direct personal insult," nor was there any danger of reactive violence against Cohen. Id.

51. In this sense the "fighting words doctrine" is not a discrete, free-standing doctrine at all, but merely a specific application of the general clear and present danger test.

It should be emphasized that the rigors of the clear and present danger test must be satisfied case by case. There was a time in our first amendment jurisprudence in which it was taken for granted that a legislature could effectively "precertify" certain identified classes of speech as satisfying the clear and present danger test. This was one of the principal themes in Gillow v New York, 268 US 652 (1952), in which the Court approved proscription of utterances which, "by their very nature, involve danger to the public peace and to the security of the State." Id at 669. You can't start a fire without a spark, and the Court was convinced that a "single revolutionary spark may kindle a fire that, smouldering for a time, may burst into a sweeping and destructive conflagration." Id.

The Court in Gillow did not require that foreseeable harm be demonstrated in each individual prosecution. Id at 670. Rather, the legislature could make a generic determination applicable to a broad class of speech, and thereby estop individuals from claiming that their particular speech posed no serious threats. Thus the Court admonished,

when the legislative body has determined generally, in the constitutional exercise of its discretion, that utterances of a certain kind involve such danger of substantive evil that they may be punished, the question whether any specific utterance coming within the prohibited class is likely, in and of itself, to bring about the substantive evil, is not open to consideration.

Id.

This device of deference to generic legislative determinations has been abandoned in contemporary first amendment doctrine. In Landmark Communications, Inc. v Virginia, 435 US 829, 843 (1978), for example, the Court stated flatly that "[d]eference to a legislative finding cannot limit judicial inquiry when First Amendment rights are at stake." And in Cohen, 403 US at 20, the Court rejected the view that the state could specify in advance language that is "inherently likely to provoke violent reaction."

52. Smolla, 47 Wash \& Lee L Rev 171 (1990) (cited in note 2).

53. See notes $32-33$ and accompanying text.

54. 391 US 367 (1968). In O'Brien, the Court upheld convictions for burning draft cards to protest the Vietnam $W$ ar. The protesters argued that burning a draft card was a form of political protest, and that Congress had purposefully intended to censor freedom of speech in amending federal law to prohibit mutilation of the cards. Id at 376. The Supreme Court refused to scratch beneath the surface of Congress' intent and upheld the convictions. Id at 376-77. O'Brien's burning of his draft card, the Court reasoned, involved a mixture of "speech" and "conduct." Id at 376. 
expression, and the governmental interests at stake are substantial, the regulation will normally be upheld even though it may have the incidental effect of interfering with speech.

A student who spray-paints a hate message on the side of a university building might thus be prosecuted for damage to the property. ${ }^{55}$ If the university were to engage in selective prosecutions, however, punishing those who desecrate university property with hate speech but ignoring desecration

Whenever "speech" and "nonspeech" elements are combined in the same activity, the Court held, the government is permitted to regulate the activity if can meet a four-pronged test:

(1) the governmental regulation must be "within the constitutional power of the Government";

(2) the regulation must further an "important or substantial governmental interest";

(3) the governmental interest must be "unrelated to the suppression of free expression"; and

(4) the "incidental restriction on alleged First Amendment freedoms" must be "no greater than is essential to the furtherance of that interest."

Id at 377 (citation omitted). The Court's application of this test in the $O^{\prime}$ Brien case itself was disingenuous-the only credible reading of Congress' intent was that it did wish to stifle dissent by banning mutilation of draft cards as a form of protest. But the basic conceptual point of $O^{\prime} B$ rien was sound and remains an integral part of modern first amendment jurisprudence. When governmental intent is truly "clean," and genuinely unrelated to the suppression of free expression, then a standard of judicial review less stringent than strict scrutiny is warranted for the incidental "spillover" effect that the law has on free speech.

55. The key here is the third prong of the O'Brien test; it is the "gatekeeper," so to speak, governing entrance to the lower standard in $O^{\prime}$ Brien. This prong is crucial; much of modern first amendment law turns upon how it is interpreted. Under prong three, the governmental interest used to justify the law must be "unrelated to the suppression of free expression." Id at 384 . What does this phrase mean? In fact, this phrase is susceptible to two different interpretations, and the level of protection for free speech in our society is largely bound up in which of those two meanings we choose.

The first possible interpretation of the phrase "unrelated to the suppression of free expression" is that government must have some reason other than a desire to censor speech as the rationale for its regulation. This seems straightforward enough. In the $O^{\prime} B$ rien case, the reason was the orderly administration of the selective service system. What could be simpler? The difficulty comes from this: all laws restricting freedom of speech are passed because of some "interest unrelated to free expression."

Governments pass laws restricting freedom of speech because they fear physical violence against persons or property, or because they are concerned about maintaining national security, or because they wish to shelter other citizens from attacks on their reputation, or invasion of their privacy, or insults to their human dignity, or because they wish to protect community morals, or promote tolerance, or encourage cohesiveness-governments pass laws restricting freedom of speech for all of these reasons and many more, and in every instance it is possible to characterize the governmental goal as "unrelated to free expression." No law abridging freedom of speech is ever promoted as a law abridging freedom of speech. The preambles to statutes never announce: "Whereas, there is a social interest in the suppression of free expression, be it enacted . . . "Because legislatures that pass laws restricting speech always have, as their ultimate goal, some perceived social interest other than suppression of speech, there is no law that could not qualify for the lenient treatment of the $O$ 'Brien test if the phrase "an interest unrelated to free expression" refers merely to that ultimate goal. Such an interpretation of $O^{\prime}$ Brien would make defending the government nice work, for it would insure that the tough, clear and present danger and strict scrutiny tests would always be bypassed. We should thus label this first interpretation of the phrase the "heretical version" of $O^{\prime} B$ rien and be constantly vigilant against its use.

The sound interpretation of the phrase "unrelated to free expression" focuses not upon the ultimate goal of the legislation, but rather upon whether the justifications for the law advanced by the government have nothing to do with the communicative aspects of the conduct being regulated. When the dangers that allegedly flow from the activity have nothing to do with what is communicated, but only with what is done, the dangers are unrelated to free expression. But when the dangers the government seeks to prevent are dangers that it fears will arise because of what is communicated, 
with other messages, this discriminatory application of the facially neutral law, based on the content of the wrongdoer's message, would violate the Constitution. ${ }^{56}$

\section{Discriminatory Conduct. Just as the first amendment does not immunize} physical attacks on persons or property, it does not immunize discriminatory conduct illegal under the equal protection clause, civil rights acts, or labor laws. Hate speech is often used as evidence of illegal discriminatory behavior. ${ }^{57}$ As long as it is the underlying discriminatory behavior and not the speech that is being regulated, the first amendment is not offended. Under the analysis in $O^{\prime} B r i e n$, the penalty exacted on speech in such cases is incidental to the governmental purpose of regulating the purely nonexpressive component of the conduct. ${ }^{58}$

then the regulation is "related to free expression," and should be subjected to the clear and present danger and strict scrutiny tests, and not to the $O^{\prime} B$ rien test.

This crucial distinction can be most easily illustrated by contrasting a "flag-burning" law with a mere "burning" law. A mere burning law-an ordinance that forbids lighting open fires in a public park-is a law passed to vindicate interests genuinely unrelated to free expression. The government might pass such a law because it believes open fires in the park present fire hazards that might cause injury to park land or patrons. The government might also pass such an ordinance as part of a more general environmental policy, concerned with the serious air pollution effects of open fires in an urban environment. Such an antiburning ordinance could have the incidental effect of suppressing speech, for it would prevent persons from burning things to express themselves. (The language of the Court in $O^{\prime} B$ rien, it should be noted, spoke in precisely these terms, referring to "the incidental restriction on alleged First Amendment freedoms." Id at 377 (emphasis added).) This incidental impact would be purely happenstance, however, for the law was passed to prevent harms that have nothing whatever to do with the communicative aspect of burning a flag, draft card, effigy, or any other symbol, but rather to prevent the harms of burning, period.

When the government bans flag-burning, by contrast, it does so to prevent harms that do arise from the communicative element of the act. Laws against flag-burning are not passed out of concern for pollution of the physical atmosphere but out of concern for pollution of the political atmosphere. The government does not like what burning the flag means. While it is true that government may have, as its ultimate goal, an altruistic concern with political cohesiveness, the justifications that it advances for banning flag-burning are based on the supposition that what is communicated by flagburning will tend to undermine that cohesiveness. This is the correct interpretation of $O^{\prime} B$ rien, and for the most part the Supreme Court has been conscientious in adhering to this interpretation. The Court has emphasized on several occasions, for example, that the test of whether a law serves purposes unrelated to the content of expression is whether it is "justified without reference to the content of the regulated speech." Ward, $109 \mathrm{~S} \mathrm{Ct}$ at 2754.

56. The constitutional violation might be conceptualized in two ways. Discriminatory application of an otherwise neutral law on the basis of a suspect class (such as racial identity) or the exercise of a fundamental right (such as free speech) triggers "strict scrutiny" under the equal protection clause and is usually a constitutional violation. Yick Wo v Hopkins, 118 US 356, 373-74 (1886). Alternatively, the act of selective prosecution might simply be used as evidence that the ostensibly content-neutral governmental interest is a sham, and the real motivating force is punishment based on the content (and, indeed, viewpoint) of the speech. This showing should disqualify the government from use of the $O^{\prime} B$ rien test, and trigger strict scrutiny under the first amendment. Under the neutrality principle, such viewpoint-based discrimination is virtually a per se constitutional violation. See notes $24-26$ and accompanying text.

57. A racist remark by a public official, for example, might be used as proof of discriminatory intent in the administration of a governmental program in a suit alleging a violation of the equal protection clause. The racist statement could be the "smoking gun" that the disparate impact of the program was the result of purposeful governmental discrimination. Similarly, racist speech might be used to demonstrate a violation of federal labor laws, see Sewell Mfg. Co., 138 NLRB 12 (1962), or as proof of housing or employment discrimination in violation of civil rights acts.

58. See note 34 and accompanying text. 
5. The Theory of Hate Speech as a Relational Harm. The harm principle of modern first amendment jurisprudence forbids punishing speech on the ground that the message is intellectually or emotionally repugnant to a vast majority. ${ }^{59}$ When the speech interferes with a "relational interest," however, it may be penalized. 60 Thus, a public figure who is ridiculed through a vicious caricature may not recover in tort merely for the emotional distress caused by the attack, but may recover for libel or invasion of privacy. ${ }^{61}$

The difference between recovery for infliction of emotional distress alone and recovery for libel or invasion of privacy goes to the heart of the harm principle. Permitting recovery for unvarnished emotional distress cannot be reconciled with core first amendment principles-no matter how we dress it up, the tort rests at bottom on the individual distress caused by the message of the speech and on the sense of collective community outrage caused by the violation of accepted rules of civility. ${ }^{62}$ These are precisely the types of harms that modern first amendment theory disqualifies as justifications for abridging speech. ${ }^{63}$ The torts of libel and invasion of privacy, however, carry additional weight; they implicate harms over and above individual psychological disturbance or collective community outrage. Libel interferes with reputation, a concept that the common law long ago reified as an interest existing outside the individual persona, an intangible asset of social or professional life that may be inventoried like any other stock in trade. ${ }^{64}$ Similarly, the four commonly accepted forms of invasion of privacy all implicate interests over and above mere infliction of emotional distress. ${ }^{65}$ If

59. See notes $27-28$ and accompanying text.

60. See text accompanying note 31 .

61. Hustler, 485 US 46.

62. The writings of Professor Robert Post on the relationship of torts such as defamation, invasion of privacy, and infliction of emotional distress to notions of community, offensiveness, and the purposes of the first amendment are exceptionally insightful. See Robert C. Post, Cultural Heterogeneity and the Law: Pornography, Blasphemy, and the First Amendment, $76 \mathrm{Cal} \mathrm{L} \mathrm{Rev} 297$ (1988); Robert C. Post, The Social Foundations of Defamation Law: Reputation and the Constitution, 74 Cal L Rev 691 (1986); Post, 32 Wm \& Mary L Rev (forthcoming) (cited in note 2); Post, 103 Harv L Rev 601 (cited in note 28 ).

63. See notes $27-30$ and accompanying text.

64. See Rodney A. Smolla, Let the Author Beware: The Rejuvenation of the American Law of Libel, 132 U Pa L Rev 1, 19 (1983).

65. For the classic restatement of the elements of the four commonly recognized forms of invasion of privacy, "false light," "intrusion," "publication of private facts," and "appropriation," see William L. Prosser, Privacy, 48 Cal L Rev 383 (1960). The tort of appropriation, or invasion of the "right of publicity," is the member of the privacy family that most clearly protects interests distinct from emotional distress; it consists of exploitation of the plaintiff's name or likeness, usually for commercial gain. See generally Harold R. Gordon, Right of Property in Name, Likeness, Personality and History, $55 \mathrm{Nw}$ U L Rev 553 (1960). The essence of false light, a close cousin of defamation, is a falsehood placing the plaintiff in a light that would be highly offensive to a reasonable person. Restatement (Second) of Torts $\S 652 \mathrm{E}$ (The American Law Institute, 1977). It thus implicates a relational interest similar to that of defamation. The tort of intrusion involves an invasion of the plaintiff's private space or solitude-such as eavesdropping on private conversations or peeping through the bedroom window. See Smolla, Law of Defamation at $\$ 10.03$ (cited in note 5) (collecting cases). Publication of private facts involves publication of true private facts that would be highly offensive to a person of ordinary sensibilities. See Sidis v F-R Publishing Corp., 113 F2d 806 (2d Cir 1940). Both intrusion and publication of private facts implicate "invasions" of interests distinct from mere outrage at a speaker's message; they are forms, so to speak, of "psychic trespass." Indeed, the 
this constitutional divide is conceptually sound, where does hate speech fall in the taxonomy of harms? Is it more like libel and invasion of privacy, or more like intentional infliction of emotional distress? The question is close. Looking back at Beauharnais v. Illinois, ${ }^{66}$ it is clear that Justice Frankfurter thought that hate speech was closely analogous to libel or invasion of privacy-and that the force of the analogy was not dissipated merely because the slur was aimed at an entire racial group.

Frankfurter observed that if a libelous utterance directed at an individual may be punished, "we cannot deny to a State power to punish the same utterance directed at a defined group, unless we can say that this is a willful and purposeless restriction unrelated to the peace and well-being of the State."67 Illinois, Frankfurter observed, did not have to look beyond its own borders "or await the tragic experience of the last three decades" (a reference to Nazi Germany) to conclude that purveyors of racial and religious hate "promote strife and tend powerfully to obstruct the manifold adjustments required for free, ordered life in a metropolitan, polyglot community." 68 Recalling events from the 1837 murder of the abolitionist Lovejoy to the 1951 riots in Cicero, Frankfurter concluded that Illinois might well deduce that racial tensions are exacerbated and more likely to flare into violence when racist messages are tolerated. 69

Frankfurter also argued that Illinois was entitled to conclude that the dignity of the individual might be inextricably intertwined with protection for the reputation of his racial or religious group. It was not for the Supreme Court, he said, to deny that the "Illinois legislature may warrantably believe that a man's job and his educational opportunities and the dignity accorded him may depend as much on the reputation of the racial and religious group to which he willy-nilly belongs, as on his own merits."70

Frankfurter's treatment of group libel as an interference with a relational interest is not without appeal, ${ }^{71}$ but current first amendment jurisprudence

intrusion tort requires no speech at all-though it is often committed as incident to gathering information.

The point here is not that these privacy torts raise no first amendment problems. The tort of publication of private facts raises such serious first amendment difficulties, for example, that its continuing existence is in genuine doubt. See Florida Star v B.J.F., 109 S Ct 2603 (1989). The point, rather, is that if these privacy torts are to have at least a fighting chance of survival under the modern first amendment, they must be understood to protect individuals from interests other than mere outrage at the content of a speaker's message. The outrage may perhaps be part of the cause of action-as in the requirement of offensiveness that pervades privacy theory-but that offensiveness may not stand alone. Rather, it must be incident to the invasion of some other more palpable interest. To the extent that some of what would pass muster under the law of torts as an invasion of privacy will not pass muster under the first amendment, the first amendment lesson is that the privacy torts should have a structural integrity distinct from sheltering the victim from distress caused by the content of speech.

66. 343 US 250.

67. Id at 258 (emphasis added).

68. Id at 258-59.

69. Id at 259 .

70. Id at 263 .

71. See Post, 74 Cal L Rev 691 (cited in note 62). 
would not accept this characterization, at least when the hate speech involves discussion of public issues. ${ }^{72}$ To put the doctrinal issues most simply, Brandenburg $v$. Ohio would not have come out differently if Ohio had chosen to prosecute the Klan under a group libel statute rather than its criminal syndicalism law. ${ }^{73}$ Brandenburg must be understood as overruling Beauharnais and eliminating the possibility of treating group libel under the same first amendment standards as individual libel. ${ }^{74}$

\section{The Public Speech/Private Speech Dichotomy. If there is an Achilles' heel to} modern first amendment jurisprudence, it is the dichotomy between speech of "general public interest or concern" and "private" speech. In a number of cases, the Supreme Court has held that first amendment rules highly protective of freedom of speech do not apply with full force-and indeed, may not apply at all-when the speech is of purely private concern. ${ }^{75}$ The public speech/private speech dichotomy is still in an early stage of evolution-the

72. See the textual discussion accompanying notes 75-80.

73. See notes $32-33$ and accompanying text.

74. The Supreme Court's most recent foray into the fact/opinion distinction in libel law further bolsters this assertion. In Milkovich, $110 \mathrm{~S} \mathrm{Ct}$ at 2706, the Court declined to create a special constitutional doctrine immunizing "opinion" from defamation liability. See note 25 . In a backhanded way, however, the Court's ruling did immunize all speech that is not factual in nature from defamation liability. The Court thus construed its prior decision in Philadelphia Newspapers, 106 S Ct 1558, as standing "for the proposition that a statement on matters of public concern must be provable as false before there can be liability under state defamation law, at least in situations like the present, where a media defendant is involved." Milkovich, $110 \mathrm{~S} \mathrm{Ct}$ at 2706 . The Court similarly relied on its prior decision in Hustler, emphasizing that an action by a public figure was precluded under the first amendment in the absence of statements that could " 'reasonably have been interpreted as stating actual facts about the public figure involved.' "Id at 2705, quoting Hustler, 485 US at 50. The Court also endorsed its prior decisions in Greenbelt Cooperative Publishing Ass' $n v$ Bresler, 398 US 6 (1970) and Letter Carriers v Austin, 418 US 264 (1974), protecting "rhetorical hyperbole." Milkovich, $110 \mathrm{~S} \mathrm{Ct}$ at 2704-05.

In Milkovich the Court thus tied first amendment requirements to the traditional common law doctrines defining what type of speech qualifies as "defamatory." Significantly, the common law excluded name-calling, insults, epithets, and verbal abuse from the definition of "defamatory." Smolla, Law of Defamation at $\$ 4.03$ (cited in note 5).

75. In Connick $v$ Myers, 461 US 138 (1983), the Court dealt with the free speech of employees not relating to general discussion on matters of public interest or concern, but on matters of "insubordination" within the hierarchy of the agency. The case involved Harry Connick, the district attorney for Orleans Parish, Louisiana, and Sheila Myers, an assistant district attorney on Connick's staff. A dispute between Connick and Myers arose when Connick tried to transfer Myers to a different section of the criminal court. Myers prepared and distributed to the other assistants in the office a questionnaire concerning office transfer policy, office morale, the need for a grievance committee, their level of confidence in superiors, and whether they felt pressure from their superiors to work in political campaigns. Connick fired Myers, declaring the questionnaire an act of "insubordination." Id at 141 .

The Supreme Court upheld the termination. Justice White noted that for "most of this century, the unchallenged dogma was that a public employee had no right to object to conditions placed upon the terms of employment-including those which restricted the exercise of constitutional rights." Id at 143. After acknowledging the Holmes position and the persistence of the right-privilege distinction, however, Justice White explicitly rejected the distinction as a legitimate framework for analysis. Id at 147.

Yet Myers still lost her case. The Court introduced a dichotomy between speech on matters of "public" concern and speech on matters of "private" concern. "When employee expression cannot be fairly considered as relating to any matter of political, social, or other concern to the community, 
Court's few invocations of the distinction have done little to define it. ${ }^{76}$ It is clear, however, that the phrase "general or public concern" is broad. Nothing in the public speech/private speech distinction, for example, rolls back the Court's expansive first amendment protection for speech on the wide range of cultural and social topics that are unrelated to politics or self-governance. ${ }^{77}$ Similarly, speech may qualify as a matter of public interest even though it occurs in settings that are not part of the general arena of public discourse. ${ }^{78}$

The confluence of first amendment doctrines that protect hate speech uttered or published during the course of discussion of issues of public concern, therefore, might not apply at all when the speech bears no plausible connection to such issues. Thus, a campus newspaper running a racist parody directed against a faculty member, or against an entire racial group, would be fully protected, even if the parody were as vulgar and mean-spirited as the caricature in Hustler Magazine, Inc. v. Falwell. Issues concerning race are quintessentially matters of public concern. But a gratuitous racial epithet uttered to a passerby in a context devoid of any plausible patina of intellectual content might be a different matter entirely. ${ }^{79}$ The brutal inarticulate speech of the heart, uttered outside of any discussion of public issues or affairs, might thus fall outside of the first amendment's protection entirely. ${ }^{80}$

\section{Summary of Permissible Controls on Hate Speech}

The exceptions to first amendment protection recognized under the negative side of free speech jurisprudence permit regulation of hate speech in

government officials should enjoy wide latitude in managing their offices, without intrusive oversight by the judiciary in the name of the First Amendment." Id at 146.

Similarly, in Dun and Bradstreet, Inc. v Greenmoss Builders, Inc, 472 US 749, 763 (1985), the Court held that its first amendment rules governing the types of damages recoverable in defamation suits did not apply to defamation actions not involving "matters of public concern." (The case arose out of an erroneous and damaging credit report.)

76. See Rodney A. Smolla, Dun \& Bradstreet, Hepps, and Liberty Lobby: A New Analytic Primer on the Future Course of Defamation, 75 Georgetown L J 1519, 1540-45 (1987).

77. See notes 19-22 and accompanying text.

78. For example, in Rankin v McPherson, 483 US 378 (1987), the Supreme Court had before it the issue of whether an employee in a Texas county constable's office could be fired for stating, upon hearing the news bulletin that someone had attempted to assassinate President Ronald Reagan, "If they go for him again, I hope they get him." Id at 380. Notwithstanding the employment setting, the Court held that this speech was clearly on an issue of "public concern," and held that the employee could not be fired. Id at $\mathbf{3 8 8}$.

79. This is

language that requires no more thought than the ability to spell; language that states no fact, offers no opinion, proposes no transaction, attempts no persuasion; language that contains no humorous punch-line, no melodic rhythm, no color or shape or texture that might pass as art or entertainment; language that embodies emotion with no elaborative gloss other than feeble minimum intellectual current necessary to power the use of words. Smolla, 47 Wash \& Lee L Rev at 183 (cited in note 2).

80. It is significant in this regard that the milestone modern first amendment decisions involving emotionally graphic speech all involved speech containing a social message. See Brandenburg, 395 US 444 (racist message); Cohen, 403 US 15 (anti-war message); Texas v Johnson, 109 S Ct 2533 (antipatriotic message); Hustler, 485 US 46 (antireligion, antihypocrisy message). Hate speech is likely to involve a social message-albeit repugnant and offensive. For hate speech to qualify as private speech, it would have to be essentially devoid of any message. 
only a small number of closely confined circumstances. Sweeping prohibitions on hate speech, patterned on the group libel notions of Beauharnais, are unconstitutional. The only prohibitions likely to be upheld are narrowly drawn restrictions on fighting words that present a clear and present danger of violence, ${ }^{81}$ or that punish physical injury to persons or property, ${ }^{82}$ or illegal discriminatory conduct, ${ }^{83}$ or that involve purely private speech in a context completely removed from discussion of issues of general or public concern. ${ }^{84}$

\section{III}

\section{Academic Freedom and Hate Speech on Campus}

\section{A. Introduction: The "Idea of a University"}

The first amendment principles canvassed above permit only the most modest controls on hate speech. But should those rules apply with full force on university campuses? If the regime of Beauharnais $v$. Illinois has been effectively overruled in the general marketplace, might not university campuses be treated as special settings, walled off from the general marketplace, in which the principles of Beauharnais still reign supreme?

From the perspectives both of first amendment jurisprudence and of notions of academic freedom, resolution of the conflicts posed by hate speech inevitably turns on how society conceives the idea of a university. What is this idea? Randolph Bourne in 1917 spoke fondly of the "old, noble ideal of a community of scholarship." 85 There is an endearing image of the university as set off from the rest of society-not disconnected or irrelevant, but still somehow specially removed, an island of retreat for the life of the mind. The phrase "academic freedom" conjures up this image of insularity. Wrapped in the phrase are the many claims and intuitions that because the university is special-specially important and specially vulnerable-policies and rules binding on the rest of society should not always apply to it. Campuses today are under pressure from many quarters to compromise the noble idea of the university as an island of intellectual inquiry and robust discourse that ought to maintain some degree of separation from the commands of the sovereign, the tantalizing seductions of gigantic financial grants, and the whimsical ebbs and flows of mass politics and prejudice.

But if a university is an island, what kind of island is it? For many, its principal distinguishing characteristic is unfettered expressive freedom. The university is a libertarian island, the one place that embraces, heart and soul,

81. See notes 50-51 and accompanying text.

82. See notes $53-56$ and accompanying text.

83. See notes $57-58$ and accompanying text.

84. Given the relatively primitive state of the "public speech/private speech" dichotomy, the legitimacy of this final "private speech" exception is far from certain. See notes 16-22 and accompanying text.

85. Randolph S. Bourne, The Idea of a University, in Carl Resek, ed, War and the Intellectuals: Essays by Randolph S. Bourne (1915-1919) 152, 154 (Harper \& Row, 1964). 
John Stuart Mill's wide-open marketplace. For others, however, Bourne's phrase "a community of scholarship" seems more apt, with emphasis on the word "community." The university is an island of equality, civility, tolerance, and respect for human dignity; a place where the contemplative and rational faculties of man should triumph over blind passion and prejudice.

These two images live side by side on campus. Most faculty, students, and administrators are attracted to both ideas and are discomfited when they conflict. ${ }^{86}$

\section{B. Universities and the Concept of Open Forums}

The free speech status of a state college or university is governed by a branch of first amendment jurisprudence known as "public forum law." 87 The Supreme Court has recognized three distinct categories of public forums. The first, the traditional or quintessential public forum, consists of places such as streets or parks that "have immemorially been held in trust for the use of the public and, time out of mind, have been used for purposes of assembly, communicating thoughts between citizens, and discussing public questions." 88 Content-based regulation of speech in a traditional public forum is governed by the strict scrutiny test: the regulation must be necessary to serve a compelling state interest, and must be narrowly drawn to achieve that end. ${ }^{89}$ Content-neutral regulation of the time, place, and manner of speech in a traditional public forum is permitted if it serves an "important," "significant," or "substantial" governmental interest, is narrowly tailored to achieve the interest, and leaves open ample alternative channels of communication. ${ }^{90}$

The second category, the designated open public forum, consists of public property opened by the state for indiscriminate use as a place for expressive

86. See notes $2-3$.

87. In exploring the idea of a university, it is necessary to distinguish between matters of constitutional law and of academic policy. State institutions, bound by the Constitution, do not enjoy unfettered freedom to choose between the libertarian and communitarian models of university life. Their choices are constricted by first amendment public forum law, which in turn controls whether the constitutional principles of the general marketplace will or will not be activated on the campus. For private universities, identical choices exist-but they are choices of policy, not constitutional law. This article examines the constitutional public forum law applicable to state universities. The constitutional law conclusions drawn herein, however, are also intended to apply fully to private universities-even though private universities are not legally bound to accept them. That, admittedly, is itself an enormously fertile ground for debate: should private universities conduct themselves as if they are bound by the first amendment? (The issue, of course, is not unique to the topic of hate speech.) The assumption made in this article is that the noble idea of a university explored here recognizes no distinction between state and private institutions, because it behooves any university that aspires to greatness to organize itself according to principles of freedom of speech that are at least as protective as those of the Constitution. But obviously, it is for private universities to ask themselves whether they feel it is appropriate to truly take the first amendment to heart. Space does not permit a full treatment of this issue in this article.

88. Hague v CIO, 307 US 496, 515 (1939).

89. Carey, 447 US at 461-62.

90. See, for example, Perry Education Assn, 460 US at 46; United States Postal Serv. $v$ Council of Greenburgh Civic Ass ns, 453 US 114, 132 (1981); Consolidated Edison Co. v Public Serv. Comm 'n, 447 US 530, 535-36 (1980). 
activity. If the government intentionally dedicates a piece of public property to the public at large for assembly and speech, then it will be bound by the same standards applicable to a traditional public forum. Content-based regulation of speech in a designated open public forum must thus satisfy the strict scrutiny test.91 A state is "not required to indefinitely retain the open character of the facility," 92 but as long as it does so, the strict scrutiny test applies. ${ }^{93}$

The third category, the nonpublic forum, consists of publicly owned facilities that have been dedicated to use for either noncommunicative or communicative purposes, but have never been designated for indiscriminate expressive activity by the general public. "[T] guarantee access to property simply because it is owned or controlled by the government." 94

The content-based regulation of speech in a nonpublic forum is not governed by the strict scrutiny test, but by a "reasonable nexus" standard. The government "may reserve the forum for its intended purposes, communicative or otherwise, as long as the regulation on speech is reasonable and not an effort to suppress expression merely because public officials oppose the speaker's view."95 Entire classes of speech thus may be excluded from a nonpublic forum. Those classes may be identified by content, as long as the exclusion is reasonable in light of the purpose of the forum and there is no discrimination among viewpoints within a class. "Control over access to a nonpublic forum can be based on subject matter and speaker identity so long as the distinctions drawn are reasonable in light of the purpose served by the forum and are viewpoint neutral."96

How should a state university campus be classified for first amendment purposes? The soundest view is to treat the campus not as one unified forum, but as subdivided into multiple forums to which differing free speech standards apply. On the grounds of every state university campus, for example, are located traditional public forums, which serve as the functional equivalent in campus life of the Boston Common, the Washington Mall, or the streets and sidewalks in front of the seat of government. Of course, the geography of campuses differs-at some universities, this traditional forum may be the open campus green or plaza, at others it may be the entrance to the student union or the main classroom building. But every state campus, like every city, should be understood to have at least one location

91. See, for example, Cornelius, 473 US at 802-03; Perry Education Ass'n, 460 US at 45-46.

92. Perry Education Assin, 460 US at 46.

93. Id. The same legal standards for regulating speech thus apply to Category I traditional forums and Category II designated forums. The only difference between the two categories is that the government has no control over the status of a traditional forum (the United States could not take the Washington Mall out of circulation as a traditional public forum) but government may by designation move a public facility in or out of Category II status. Cornelius, 473 US at 802-03; Perry, 460 US at $46-47$.

94. Greenburgh Civic Ass'ns, 453 US at 129.

95. Perry, 460 US at 46 (emphasis added), citing Greenburgh Civic Ass'ns, 453 US at $131 \mathrm{n} 7$.

96. Cornelius, 473 US at 806 (emphasis added). 
permanently dedicated to wide-open discourse, a first amendment "free fire zone" in which the principles of free speech in the open marketplace apply with undiminished force. ${ }^{97}$

In addition, most state universities should be treated as having turned large parts of their campuses into designated public forums. The Supreme Court's most significant foray into this issue came in its 1981 decision in Widmar $v$. Vincent, ${ }^{98}$ involving the University of Missouri at Kansas City. The university's stated policy was to encourage the activities of student organizations, and it officially recognized over 100 student groups.99 The university regularly provided facilities for the meetings of registered organizations; students paid an activity fee to help defray the costs to the university. ${ }^{100}$ From 1973 until 1977, a registered religious group named Cornerstone, an organization of evangelical Christian students from various denominational backgrounds, ${ }^{101}$ regularly sought and received permission to conduct its meetings in university facilities. ${ }^{102}$ In 1977 , however, the university informed the group that it could no longer meet in the university's buildings. ${ }^{103}$ The exclusion was based on a regulation, adopted in 1972 by the university, forbidding the use of university facilities "for purposes of religious worship or religious teaching." 104 The university defended its regulation on the grounds that the prohibition was necessary to avoid a violation of the establishment clause of the first amendment. ${ }^{105}$ The Supreme Court rejected this defense and held the Missouri restriction unconstitutional. ${ }^{106}$ The Court reasoned that permitting a student religious group to use the university's facilities on the same terms as other student groups could not be construed as an implicit endorsement of the religious group's message, and that therefore the establishment clause was not violated by letting the religious group in. ${ }^{107}$ The University had designated its facilities as open forums, the Court held, and consequently could not discriminate against religious speech. 108 "The Constitution forbids a State to

97. This requirement is analogous to so-called "green space" restrictions common in modern land use and environmental regulation. In order to preserve the environmental quality of life in every area developed for residential or business use, green space regulations require developers to maintain a specified ratio of developed spaces to open, or green, spaces. We might think of the general marketplace of speech as the green spaces of discourse. Governments own a substantial amount of the space on which this discourse occurs-public parks, streets, sidewalks, plazas, stadiums, auditoriums, and so on. It is essential that, in any given community, sufficient open physical space be dedicated to the general marketplace. For unless we think of these spaces as subject to a perpetual public "easement" for free speech, government could dramatically curtail much of the speech most vital to the general marketplace, such as mass protest demonstrations.

98. 454 US 263 (1981).

99. Id at 265 .

100. Id.

101. Id at $265 \mathrm{n} 2$.

102. Id at $\mathbf{2 6 5}$.

103. Id.

104. Id.

105. Id at 270-71.

106. Id at 267.

107. Id at 273-74.

108. Id at 267-70. 
enforce certain exclusions from a forum generally open to the public," the Court stated, "even if it was not required to create the forum in the first place."109

What does Widmar really mean? Does it require universities to permit all forms of hate speech on campus that must be tolerated in the general marketplace? Widmar might be understood as standing for the proposition that, by virtue of the large quantity of diverse speech customarily permitted on state campuses, they are in all respects designated open public forums. That view, however, reads more into Widmar than it will legitimately bear, since there was never really any contest concerning the open forum status of the particular university facilities at issue in Widmar. ${ }^{110}$

The Widmar decision does not stand for the proposition that a state university is compelled by the first amendment to treat all places at all times as open public forums. As support for this assertion, consider the following problem. Justice White argued in dissent in Widmar that the university should be permitted to exclude religious worship and services from its facilities, even if it were required by the first amendment to permit access to other forms of religious speech. ${ }^{11}$ Thus the university would have to permit a Catholic student group access to its classrooms for a meeting, but not permit access for the celebration of Mass. A majority of the Court, however, rejected Justice White's argument, refusing to accept any distinction between religious worship and other forms of religious speech in an open forum.

Now imagine that a professor at the University of Missouri wishes to open his history of religion class, which is conducted in the same classroom in which the student religious group regularly meets by instructing the students to bow their heads and join him in reciting the Lord's Prayer. Surely this instruction would violate the establishment clause. The act of a university official leading a captive group of students in a prayer is totally distinct from a group of students meeting voluntarily on their own to pray. The professor could not successfully defend his actions by asserting that the classroom is an open forum under Widmar and that, under first amendment principles or principles of academic freedom, he has a right to lead his students in prayer to commence his class. The constitutional calculus changes as the function of

109. Id at 267-68.

110. There was no contest in Widmar over the open public forum status of the classroom facilities (outside of normal class usage) on the University of Missouri's Kansas City campus. The university did not defend its position on the basis that it had created only a nonpublic forum for these facilities, nor did it attempt to avoid application of the strict scrutiny test. Rather, the university argued that its interest in maintaining strict separation of church and state created a compelling state interest sufficient to satisfy strict scrutiny review. The Supreme Court in Widmar therefore accepted as a given that the facilities at issue on the Missouri campus were open public forums, and it constantly emphasized the breadth of those forums. The Court referred to the Missouri campus as "a forum generally open to the public," id at 268 , "a public forum," id at 270 , a "public forum, open to all forms of discourse," id at 273 , an "open forum," id at 274 , and "a forum generally open to student groups." Id at 277. The Court noted that "the forum is available to a broad class of nonreligious as well as religious speakers; there are over 100 recognized student groups at UMKC." Id at 274.

111. Id at 282-89 (White dissenting). 
the classroom changes. ${ }^{112}$ Principles of academic freedom may well give him a large measure of freedom to choose how he will present the history of religion in that classroom, but that freedom does not extend to actually conducting religious worship or services. The very distinction between religious speech and religious worship advanced by Justice White but rejected by a majority of the Court in the context of the university's open forum would be valid and controlling during actual class times.

An analogous process applies to hate speech. There are settings on the campus in which the rule of Beauharmais, and not the rule of Brandenburg, should apply. ${ }^{13}$ When considered against the backdrop of the complexities of academic freedom, this distinction is most vividly demonstrated by examining the power of a university to discipline its own employees, including its administrators and faculty, for hate speech that would normally be protected by the first amendment. ${ }^{114}$

Principles of free speech and academic freedom should certainly be understood to give faculty a large measure of independence in how they present materials in class on matters relating to race, sex, or sexual orientation. Viewpoint discrimination should not be permitted, even when the university regards the view espoused by the professor as repugnant. Thus a professor should have the right to espouse bona fide academic opinions concerning racial characteristics or capabilities, even though most people of good will and good sense on the campus would find the opinions loathsome. It does not follow, however, that the professor would have the freedom to engage in racist, sexist, or homophobic speech attacks during class, even though those attacks might be protected in the open marketplace. The speech at issue in Beauharnais and Brandenburg was the same mindless racist diatribe. The professor would have a right to engage in that sort of hate speech in the open forums on campus, but not in the classroom, where the rule of Beauharnais should instead govern.

112. See Rabban, 53 L \& Contemp Probs 227 (cited in note 3).

113. An easy illustration involves a state university radio station run by students. Under the Supreme Court's ruling in FCC v Pacifica Foundation, 438 US 726, 747-52 (1978), the government is permitted to exclude "indecent" speech from the airwaves, even though that speech would be fully protected in print media. The Pacifica ruling clearly supports the FCC's authority to ban racist speech from the airwaves. On the radio, it is the Beauharnais first amendment and not the Brandenburg version that controls. No state university radio station could successfully claim a first amendment right to be opted out of the rule of Pacifica on the theory that universities are open public forums in which Brandenburg principles always apply. At least for that pocket of university discourse-the radio waves-the more restrictive notions of Beauharnais and Pacifica would trump the open forum principles of Widmar.

114. Academic freedom has an institutional and an individual component. In institutional terms, it embodies the principle that universities should be kept largely free of interference from outside forces, including the government. Much more complex is the individual component, in which members of the university community stake out claims against interference from the university. A faculty member or student may thus claim an individual academic freedom right to espouse theories of racial superiority that run contrary to institutional university policy. See William W. Van Alstyne, Academic Freedom and the First Amendment in the Supreme Court of the United States: An Unhurried Historical Review, 53 L \& Contemp Probs 79 (Summer 1990); Rabban, 53 L \& Contemp Probs 227 (cited in note 3 ). 
Academic freedom should be understood as making the professor an intellectual free agent, but not a behavioral free agent. The members of the faculty act as the representatives of the university in the classroom both on matters intellectual and on matters not plausibly related to intellectual positions. The university is under a constitutional obligation to refrain from stigmatizing hate speech and may likewise require the faculty, as its representatives, to refrain from stigmatizing hate speech in the classroom. ${ }^{115}$ Just as a university is required to prevent its faculty from leading students in prayer to begin class sessions-even though that prayer would be constitutionally protected in other contexts-so too the university should be understood as at least permitted (and arguably required) to police gratuitous hate speech by faculty in classroom settings. It should be emphasized that this notion that a university has greater power to control hate speech by faculty or administrators in settings such as classrooms is not a mechanical invocation of the right-privilege distinction, which has been thoroughly discredited in modern constitutional law. ${ }^{116}$ Under this distinction, which once dominated American constitutional law, government could attach whatever conditions it pleased to the receipt of governmental largess, including the surrender of constitutional rights that the recipient would otherwise enjoy. Thus, a faculty member could be told by the university, "You are free to exercise your freedom of speech to engage in constitutionally protected hate speech to your heart's content, but if you accept a university appointment here, you do so on the condition that you refrain from exercising that right." The faculty member may have a constitutional right to freedom of speech, but no constitutional right to be a faculty member. ${ }^{117}$ Though the distinction has been discredited, the underlying "beggars can't be chosers" premise of the distinction has stamina, and it continues to surface-sometimes in disguise-

115. Stigma is at the heart of modern equal protection analysis. In Brown v Board of Educ, 347 US 483, 494 (1954), the Court stated that to separate black children from white children solely because of their race "generates a feeling of inferiority as to their status in the community that may affect their hearts and minds in a way unlikely ever to be undone." As Professor Charles Lawrence explains, Brown held that separate was inherently unequal "because of the message that segregation conveys-the message that black children are an untouchable caste, unfit to be educated with white children." Lawrence, 1990 Duke L J at 439 (cited in note 2) (emphasis in the original). In Andersonv Martin, 375 US 399 (1964), the Court struck down a state law that required designation of the race of candidates on ballots. The Court reasoned that while no one doubts that voters in the privacy of the voting booth may take racial identity into account in casting their votes, the government may not encourage that accounting by placing the race of the candidate on the ballot. Id at 402 . The specification of a candidate's race is different in kind from the designation of a candidate as "Republican" or "Democrat." Id at 402-03. To identify candidates by race, the Court held, places "the power of the State behind a racial classification that induces racial prejudice at the polls." Id at 402. Justice Brennan in Regents of the University of California v Bakke, 438 US 265 (1978), pronounced as a "cardinal principle" the proposition that "racial classifications that stigmatize-because they are drawn on the presumption that one race is inferior to another or because they put the weight of government behind racial hatred and separatism-are invalid without more." Id at 357-58 (Brennan concurring in part and dissenting in part).

116. See William W. Van Alstyne, The Demise of the Right-Privilege Distinction in Constitutional Law, 81 Harv L Rev 1439 (1968).

117. See McAuliffe v Mayor of New Bedford, 155 Mass 216, 220, 29 NE 517,517 (1892) ("The petitioner may have a constitutional right to talk politics, but he has no constitutional right to be a policeman."). 
in modern cases. ${ }^{118}$ But at least in first amendment cases, the Supreme Court consistently refuses to accept the distinction. ${ }^{119}$ Thus, in controlling the speech of faculty or administrators, the university is emphatically not permitted to rely merely on the leverage of employment, but must justify its regulation of speech according to whatever first amendment principles would otherwise apply.

The principle just stated, however, does not mean that the status of employment is constitutionally irrelevant to the first amendment analysis. The particular circumstances of the employment context may supply the government with justifications for regulating speech that would not exist otherwise. Rather than invoking the right-privilege distinction, the government simply would apply general first amendment principles to the specific facts of a case. When a governmental employee speaks in part for the government, the situation implicates a governmental interest in controlling the content of its own speech and ensuring that it is not, for example, racially or sexually abusive; 120 the presence of this interest therefore creates a justified opportunity for regulation.

The hate speech of students on campus is more problematic. If the setting were high school or elementary school, the role of the school as an inculcator of civic values would permit Beauharnais-style controls on the hate speech of students. ${ }^{121}$ But college students are adults. Does the idea of a university contemplate a role for the institution as an inculcator of what might be called academic values, as opposed to academic freedom? Might not the university say that part of its legitimate mission is to teach students how to contend vigorously within the marketplace of ideas while nevertheless observing

118. See Rodney A. Smolla, The Reemergence of the Right-Privilege Distinction in Constitutional Law: The Price of Protesting Too Much, 35 Stan L Rev 69 (1982); Rodney A. Smolla, Preserving the Bill of Rights in the Modern Administrative-Industrial State, 31 Wm \& Mary L Rev 321 (1990).

119. See, for example, Rutan v Republican Party of Illinois, $110 \mathrm{~S} \mathrm{Ci} 2729,2735-36$ (1990).

120. See University of Pennsylvania, $110 \mathrm{~S} \mathrm{Ct}$ at $587 \mathrm{n} 6$ ("Where, as was the situation in the academic-freedom cases, government attempts to direct the content of speech at public educational institutions, complicated First Amendment issues are presented because government is simultaneously both speaker and regulator."). That the government is "simultaneously both speaker and regulator" certainly does not mean that the government has carte blanche-for that would be to reintroduce surreptitiously the right-privilege distinction. The notion of simultaneously speaking and regulating, indeed, is easily abused. In Meese $v$ Keene, 481 US 465 (1987), for example, the Supreme Court disingenuously applied this distinction, treating the governmental requirement that foreign films be labeled as "propaganda" as a form of government "speech," when in fact it was purely a form of regulation. See Rodney A. Smolla \& Stephen A. Smith, Propaganda, Xenophobia, and the First Amendment, 67 Or L Rev 253, 280-83 (1988). The Court's market-participant exception to the commerce clause is a useful analogy. States are exempted from normal commerce clause restrictions when they act as market participants because, as mere participants, they do not impede private trade in the national marketplace. See Reeves, Inc., v Stake, 447 US 429, 439 (1980). This immunity is stripped, however, when the state exerts influences on the market beyond whatever natural force it commands as a competitor. See South-Central Timber Development Inc. $v$ Wunnicke, 467 US 82, 97-98 (1984).

121. See Hazelwood School Dist. v Kuhlmeier, 484 US 260, 266-67 (1988); Bethel School Dist. No. $403 v$ Fraser, 478 US 675, 683 (1986). 
certain norms of civility? ${ }^{122}$ Might not the university claim that part of its mission is to encourage the triumph of the rational and contemplative sides of the intellect over passion and prejudice? ${ }^{123}$ The answer to these questions is bound up in yet one final aspect of the idea of a university-namely, how universities teach.

\section{IV}

\section{Conclusion}

Let there be no doubt that hate speech on campus should be fought with all the vigor a university can muster. Hate speech is an abomination, a rape of human dignity. And let there be no inhibition in punishing hate speech in any of the contexts in which speech may be punished under recognized first amendment doctrines-as when it poses a clear and present danger of violence, ${ }^{124}$ or when it is intertwined with actual discriminatory conduct. ${ }^{125}$

But outside those narrowly defined first amendment categories, the battle against hate speech will be fought most effectively through persuasive and creative educational leadership rather than through punishment and coercion. The conflict felt by most administrators, faculty, and students of good will on most American campuses is that we hate hate speech as much as we love free speech. The conflict, however, is not irreconcilable. It is most constructively resolved by a staunch commitment to free expression principles, supplemented with an equally vigorous attack on hate speech in all its forms, emphasizing energetic leadership and education on the academic values of tolerance, civility, and respect for human dignity, rather than punitive and coercive measures. ${ }^{126}$ In this respect both of the grand ideas of a university are vindicated. The sense of a community of scholars, an island of reason and tolerance, is the pervasive ethos. But that ethos should be advanced with

122. Thus the validity of the marketplace of ideas concept might be understood as contingent on a commitment to rational thinking. See Frederick Schauer, Free Speech: A Philosophical Enquiry 25-26 (Cambridge Univ Press, 1982).

123. There was a time in which even mainstream free speech jurisprudence seemed to emphasize the intellectual over the emotional. As Justice Frankfurter put it in Niemotko $v$ Maryland, 340 US 268 (1951), "A man who is calling names or using the kind of language which would reasonably stir another to violence does not have the same claim to protection as one whose speech is an appeal to reason." Id at 282 (Frankfurter concurring). "Back of the guarantee of free speech," said the Court in 1941, "lay faith in the power of an appeal to reason by all the peaceful means for gaining access to the mind." Milk Wagon Drivers Union of Chicago, Local 753 v Meadowmoor Dairies, Inc., 312 US 287, 293 (1941). This split between the reason and passion has now largely been swept away by the emotion principle in modern first amendment jurisprudence. See notes 27-28 and accompanying text. It still appears, however, in those areas in which general free speech doctrines do not apply. In the obscenity context, for example, the Court has distinguished control of obscene speech from "control of reason and intellect." Paris Adult Theatre I $v$ Slayton, 413 US 49, 67 (1973).

124. See notes 50-51 and accompanying text.

125. See notes 57-58 and accompanying text. Hate speech on campus should thus be punished in any of the situations in which such punishment is permitted under the general first amendment rules discussed in Part II of this article. See notes 1-3 and accompanying text.

126. See Robert M. O'Neil, Colleges Should Seek Educational Alternatives to Rules that Override the Historic Guarantees of Free Speech, Chron Higher Educ B 1 (October 18, 1989); Report of Workshop on Racist and Sexist Speech on College and University Campuses, The Annenberg Washington Program of Northwestern University, April 12, 1990 (copy on file with author). 
education, not coercion. It should be the dominant voice of the university within the marketplace of ideas; but it should not preempt that marketplace. 
